O'Reilly, E.L., and Eckersall, P.D. (2014) Acute phase proteins: a review of their function, behaviour and measurement in chickens. World's Poultry Science Journal, 70 (1). pp. 27-44. ISSN 0043-9339

Copyright (C) 2014 World's Poultry Science Association

A copy can be downloaded for personal non-commercial research or study, without prior permission or charge

Content must not be changed in any way or reproduced in any format or medium without the formal permission of the copyright holder(s)

When referring to this work, full bibliographic details must be given

http://eprints.gla.ac.uk/96326

Deposited on: 28 August 2014

Enlighten - Research publications by members of the University of Glasgow http://eprints.gla.ac.uk 


\title{
Acute phase proteins: a review of their function, behaviour and measurement in chickens
}

\author{
E.L. O'REILLY* and P.D. ECKERSALL \\ Institute of Biodiversity, Animal Health and Comparative Medicine, College of \\ Medical, Veterinary and Life Sciences, University of Glasgow, Bearsden Road, \\ Glasgow, G61 1QH, United Kingdom \\ *Corresponding author: e.o'reilly1@research.gla.ac.uk
}

This review brings together and consolidates the large amount of research on acute phase proteins (APPs) that has been undertaken in chickens. Acute phase proteins are secreted from the liver as a result of inflammation or infection that can be measured in plasma. They have been well-characterised in other farm animal species and have been measured in a wide variety of poultry research areas. The acceleration in chicken APP research is in response to increased interest in ways the immune responses of the chicken can be measured and compared during infection or environmental or nutritional changes. All APPs that have been identified and characterised in chickens are described in the following review and their responses during infection discussed. The APPs are tabulated with basal values and classification to provide a comparative and useful reference. The ways APPs can be measured in chickens and the assays available are also described. This review will detail the functions of the positive APPs in chickens and their behaviour during an APR.

Keywords: chicken; acute phase protein; biomarker; infection

\section{Introduction}

The acute phase response (APR) is an early and non-specific systemic reaction of the innate immune system to local or systemic disturbances caused by trauma, infection, stress, surgery, neoplasia or inflammation, the goal of which is re-establishment of homeostasis and healing (Gruys et al., 2005; Cray et al., 2009; Eckersall and Bell, 2010). At the site of infection or location of tissue injury, pro-inflammatory cytokines and chemokines are released (Gruys et al., 2005). Cytokines and chemokines are protein and peptide mediators secreted by cells which play a key role in immune and inflammatory responses through activation and regulation of other cells and tissues (Wigley and Kaiser, 2003). These inflammatory mediators initiate and modulate the 
APR, diffusing into the extracellular fluid and circulating in blood. Cytokines activate receptors on different target cells leading to a systemic APR and resulting activation of the hypothalamic-pituitary-adrenal axis, reduction in growth hormone secretion, and a number of physical changes clinically characterised by pyrexia, anorexia and catabolism of muscle cells (Gruys et al., 2005). Pro-inflammatory cytokines and chemokines together with nitric oxide and glucocorticoids activate hepatocytic receptors in the liver with resultant changes in protein synthesis and secretion. As a result within the first few hours of an APR, there are measureable changes in the concentration of several plasma proteins referred to as acute phase proteins (APPs) (Gruys et al., 2005).

The plasma concentrations of pro-inflammatory cytokines which increase within hours of the initiating stimulus are rapidly cleared from the circulation. Acute phase protein plasma concentrations are detectable for longer periods and are often proportional to the severity of the stimulus. As such APP measurements are widely used as disease biomarkers and for prognostication in human and veterinary medicine and are increasingly used in varied areas of research.

Acute phase proteins can increase or decrease during an APR and these are termed positive APPs or negative APPs respectively. Albumin is the most abundant plasma protein and represents a major negative acute APP. Due to selective loss by the renal and gastrointestinal systems or decreased hepatic synthesis, plasma albumin concentration decreases during an APR. In chickens, albumin concentrations decrease to $50-75 \%$ of normal concentrations (Grieninger et al., 1986; Adler et al., 2001). Positive APPs are further classified as minor, moderate or major APPs according to the magnitude and duration of increase during the APR. Major APPs increase 10 - 1000 fold, moderate APPs increase 4 - 10 fold and minor APPs represent those with only slight, 2 3 fold increases.

Major APPs tend to increase markedly within the first 48 hours of the triggering event and decline rapidly due to a short half life. Moderate and minor proteins tend to increase more slowly, peak at 2-3 days and have more prolonged duration (Eckersall and Bell, 2010). Table 1 details the chicken APPs documented to date and, using published results, the basal levels and classification of minor, moderate or major. As well as the liver, APPs can also be synthesised in other tissues and organs. Although extra-hepatic expression of APPs does not account for the origin of the majority of APPs the contribution that other tissues make can be locally significant and furthermore, the expression pattern of an APP can vary between tissues.

APPs are involved in many crucial metabolic and immune pathways and have roles that include scavenging extracellular haemoglobin, iron and free radicals and direct antibacterial and antiviral activity. The response of APPs to various pathogenic challenges and other disruptions in homeostasis varies between species. APP profiles from both companion and farm animal species have been well documented, and in many veterinary species these clinical parameters are used diagnostically and for understanding the pathogenesis of important diseases (Petersen et al., 2004; Eckersall and Bell, 2010). 
Table 1 Basal levels of chicken APPs and their described behaviour during an APR.

\begin{tabular}{|c|c|c|c|c|}
\hline APP & Abbreviation & $\begin{array}{l}\text { Normal serum } \\
\text { concentrations }\end{array}$ & Reference & Classification \\
\hline Albumin & $\mathrm{Al}$ & $\begin{array}{l}11.08 \pm 1.34 \mathrm{~g} / \mathrm{L} \\
20 \mathrm{~g} / \mathrm{L}(\text { Plasma }) \\
15 \mathrm{~g} / \mathrm{L} \text { (Serum) }\end{array}$ & $\begin{array}{l}\text { Inoue et al., } 1997 \\
\text { Hrubec et al., } 2002 \\
\text { Hrubec et al., } 2002\end{array}$ & Negative \\
\hline $\begin{array}{l}\alpha 1 \text {-acid } \\
\text { Glycoprotein }\end{array}$ & AGP & $\begin{array}{l}161.8 \pm 25.8 \mathrm{mg} / \mathrm{L} \\
228 \pm 20 \mathrm{mg} / \mathrm{L}\end{array}$ & $\begin{array}{l}\text { Inoue et al., } 1997 \\
\text { Takahashi et al., } 1998\end{array}$ & Moderate \\
\hline Ceruloplasmin & $\mathrm{CP}$ & $30 \mathrm{mg} / \mathrm{L}$ & Disilvestro and Harris, 1985 & Minor/Moderate \\
\hline Fibrinogen & FB & $\begin{array}{l}0.99( \pm 0.11) \mathrm{g} / \mathrm{L} \\
3.379( \pm 0.485) \mathrm{g} / \mathrm{L} \\
2.8( \pm 0.05) \mathrm{g} / \mathrm{L}\end{array}$ & $\begin{array}{l}\text { Georgieva et al., } 2010 \\
\text { Nazifi et al., } 2010 \\
\text { Amrani et al., } 1986\end{array}$ & Minor \\
\hline Fibronectin & FN & $0.31( \pm 0.4) \mathrm{g} / \mathrm{L}$ & Amrani et al., 1986 & Minor \\
\hline Haemopexin & HX & $0.15 \mathrm{~g} / \mathrm{L}$ & Buyse et al., 2007 & Minor \\
\hline $\begin{array}{l}\text { Mannan } \\
\text { binding lectin }\end{array}$ & MBL & $\begin{array}{l}0.4-37.8 \mathrm{mg} / \mathrm{L} \\
(\mathrm{mean} 5.8( \pm 4.0) \\
\mathrm{mg} / \mathrm{L}) \text { Over } 10 \\
\text { weeks old }\end{array}$ & Laursen and Nielsen, 2000 & Minor \\
\hline Ovotransferrin & OVT & $\begin{array}{l}0.90 \pm 0.06 \mathrm{~g} / \mathrm{L} \\
1.18( \pm 0.13) \mathrm{g} / \mathrm{L}\end{array}$ & $\begin{array}{l}\text { Xie et al., } 2002 \mathrm{~b} \\
\text { Rath et al., } 2009\end{array}$ & Minor/Moderate \\
\hline PIT54 & - & $\begin{array}{l}0.100( \pm 0.020) \mathrm{g} / \mathrm{L} \\
1.2 \mathrm{~g} / \mathrm{L} \\
0.09 \mathrm{~g} / \mathrm{L} \\
0.05 \mathrm{~g} / \mathrm{L}\end{array}$ & $\begin{array}{l}\text { Georgieva et al., } 2010 \\
\text { Millet et al., } 2007 \\
\text { Nazifi et al., } 2011 \\
\text { Nazifi et al., } 2010\end{array}$ & Minor \\
\hline $\begin{array}{l}\text { Serum } \\
\text { amyloid A }\end{array}$ & SAA & $\begin{array}{l}0.15 \pm 0.02 \mathrm{mg} / \mathrm{L} \\
0.166 \pm 0.17 \mathrm{mg} / \mathrm{L} \\
1.590 \pm 0.0041 \\
\mathrm{mg} / \mathrm{L} \\
1.56 \pm 0.13 \mathrm{mg} / \mathrm{L}\end{array}$ & $\begin{array}{l}\text { Alasonyalilar et al., } 2006 \\
\text { Sevimli et al., } 2005 \\
\text { Nazifi et al., } 2010 \\
\text { Nazifi et al., } 2011\end{array}$ & Major \\
\hline
\end{tabular}

\section{Acute phase proteins}

\section{SERUM AMYLOID A}

Serum amyloid A (SAA) is a major vertebrate APP and in most species is the most sensitive protein of the APR. In mammals SAA can be induced from resting levels by more than 1000 fold, implying an important beneficial role in host defence (Eriksen et al., 1993; Uhlar and Whitehead, 1999). In mammals, multiple SAA genes and proteins which are strongly induced during an APR have been described (Uhlar and Whitehead, 1999; Upragarin et al., 2005). In contrast only one SAA gene has been identified in the chicken genome (Ovelgönne et al., 2001).

Modulating lipoprotein transport and metabolism during an APR is a major function of SAA. This is because it allows cholesterol to remain in damaged tissues where it is needed for repair and regeneration of membranes and to transport cholesterol and clear lipid debris from bacteria and damaged areas of tissue (Eriksen et al., 1993; Landman, 1998). During an APR, SAA prevents oxidative tissue damage and can recruit immune cells to localised areas of inflammation (Uhlar and Whitehead, 1999). SAA is immunomodulatory, inhibiting pyrexia and down regulating pro-inflammatory events during an APR (Shainkin-Kestenbaum et al., 1991; Uhlar and Whitehead, 1999). In both mammals and birds, persistently elevated serum SAA levels, together with ongoing inflammatory and/or infectious disease may result in the formation of AA amyloid protein. The accumulation of this proteinaceous SAA derivative in organs and tissues gives rise to the disease AA amyloidosis (Röcken and Shakespeare, 2002). 
AA amyloidosis in chickens and other Galliform species was rare until Landman et al. (1994) reported a new syndrome of avian amyloidosis in a flock of heavy breed, brown layer hens. Birds showed signs consistent with chronic arthritis, with inflammatory lesions in the joints and tendon sheaths. These lesions were found to be amyloid giving rise to a new arthropathic classification of amyloidosis in birds, of which Galliformes are predisposed (Landman, 1998). Serum amyloid A, when investigated in amyloidotic birds was found to be significantly higher than in healthy controls (Alasonyalilar et al., 2006).

Nazifi et al. $(2010 ; 2011)$ found significant increases in SAA in chickens infected with infectious bursal disease virus (IBDV) and infectious bronchitis (IB) virus. These studies show only mild, one and a half to two fold increases in plasma SAA concentration in response to the viral infections. Earlier work by Upragarin (2005) found SAA increased as a result of turpentine and Staphylococcus aureus injection with SAA levels increasing from undetectable levels pre-injection to increases of 100-1000 fold 12 hours post injection. At 72 hours post injection the mean SAA concentration of injected birds was $77.23 \mathrm{mg} / \mathrm{L}$. Alasonyalilar et al. (2006) found severely amyloidotic birds to have mean serum SAA concentration of $42.53 \mathrm{mg} / \mathrm{l}$. However, in this latter study the control birds had serum concentrations of $8.48 \mathrm{mg} / 1$, much higher than control levels reported in Nazifi et al. $(2010 ; 2011)$ and Upragarin (2005). The study by Upragarin (2005) is the only one to use an ELISA utilising specific chicken SAA antibody, the others use a Murine antibody. Further work is required to develop a chicken specific antibody assay to allow further study to determine the effects of bacterial and viral infections of SAA concentrations in chickens.

\section{A1-ACID GLYCOPROTEIN}

$\alpha 1$-acid glycoprotein (AGP) is a highly glycosylated protein synthesised and secreted by hepatocytes (Murata et al., 2004; Ceron et al., 2005). Like albumin, $\alpha 1$-acid glycoprotein is an important binding protein in plasma and a natural antiinflammatory agent. It may help with the clearance of lipopolysaccharide (LPS), by binding directly with LPS and neutralising its toxicity (Murata et al., 2004). $\alpha 1$-acid glycoprotein, a moderate APP in most mammals, appears to have a significant role in the early stages of inflammation and infection in chickens.

A number of studies have investigated AGP in chickens in response to both bacterial and viral infection. Following a single Escherichia coli LPS injection AGP plasma concentrations increased significantly 12 hours post injection with serum levels increasing four-fold to peak 24 hours post injection (Takahashi et al., 1998). Nakamura et al. (1998) found infections with $E$. coli LPS resulted in an increase in AGP that peaked 48 hours post infection with a return to normal levels over 7 to 14 days. Repeated injections of E. coli LPS was found to lower the responses of plasma AGP concentrations (Takahashi et al., 1995) while repeated injections of LPS at different concentrations resulted in different AGP profiles, with the higher concentration of LPS giving higher AGP values (Takahashi et al., 1998). Age and sex do not significantly alter AGP concentrations (Takahashi et al., 1995). Adler et al. (2001), using Salmonella typhimurium LPS and turpentine to illicit an APR found AGP levels increased four-fold, peaking 24 hours post infection before returning to normal levels six days post infection.

A number of studies have investigated AGP during viral infections both with and without vaccination. Experimental infection with infectious bronchitis (IB) and infectious larygotracheitis virus (ILTV) increased AGP serum concentrations, with AGP higher in the IB than the ILTV infected birds (Nakamura et al., 1996). Inoue et al. (1997) found significant increases in serum AGP as a result of infection with a highly virulent 
infectious bursal disease virus (IBDV) strain and a virulent IBDV reference strain. The highly virulent strain increased AGP concentrations six fold and the virulent reference strain three fold. The chickens infected with the highly virulent strains also had extensive lesions in addition to the severe bursal lesions. Chickens receiving the attenuated vaccine strain of IBDV showed only a slight increase in AGP and did not develop any lesions in the bursa or liver (Inoue et al., 1997). Chickens challenged with low pathogenic avian influenza (LPAI) showed increases in AGP up to 48 post infection; however those that received LPAI vaccine were shown to have significantly lower AGP concentrations than unvaccinated controls (Sylte and Suarez, 2012).

AGP is a highly glycosylated APP, and several AGP glycoforms may be present normally in plasma. The glycosylation degree of AGP may be dramatically modified during disease (Ceciliani and Pocacqua, 2007). To study the glycan composition of AGP lectins, proteins that bind to specific carbohydrate groups can be used. The degree of branching of AGP can be studied by means of the interaction with the lectin concanavalin A (con A), that binds to $\alpha$-linked mannose residues, two mannose molecules being required to interact with the lectin (Ceciliani and Pocacqua, 2007). Inoue et al. (1997) investigated the reactivity of AGP to con A in chickens experimentally infected with infectious bursal disease virus (IBDV). In control chickens of the total AGP, 47\% was con A un-reactive and $63 \%$ con A reactive AGP. Inoculating birds with the highly virulent IBVD strain, saw con A reactive AGP increase to $80 \%$ of total AGP in the early stages of infection and infection with LPS increased con A to $87 \%$ of the total AGP (Inoue, et al., 1997). The biological effects of AGP are dependent upon its glycosylation, with con-A un-reactive AGP exhibiting a stronger inhibitory effect of lymphocyte proliferation than the Con-A reactive. In addition, the inhibitory effects of AGP on neutrophil superoxide anion generation depends on the glycan structure with con A un-reactive being less inhibitory that the con A reactive (Inoue et al., 1997). Although very little research has been undertaken on the glycosylation of chicken AGP it is clear from this work that the glycosylation pattern was modified as a result of IBDV.

$\alpha 1$-acid glycoprotein is one of the most widely measured APPs in chickens owing to the commercial availability of easy to use and chicken specific AGP kits (ECOS Institute, Miayagi, Japan). As a result AGP measurement has been used in a wide variety of poultry research areas most notably in the area of nutrition where experimental diets are followed by an immunogen challenge usually in the form of a bacterial LPS and the AGP concentration determined. The changes in AGP concentrations as a result of nutritional changes have been particularly well documented by Takahashi et al. (1995; 2002; 2009) (Table 2)

The use of APPs as a physiological marker for overall health and welfare is another potential use of APP measurement. In comparing different egg laying systems Salamano et al. (2010) compared the serum concentrations of AGP and albumin. Mean AGP serum concentrations, when measured at two weeks and two months post arrival at accommodation, were higher in hens kept in conventional and modified cages than hens in a free range system. However after four months the free range hens had higher mean AGP than both modified and conventionally caged groups, with the mean AGP of the free range hens having increased significantly from two months previously. AGP was used to evaluate stress and immunity of organically produced broilers compared to traditionally produced broilers. The organic broilers had serum AGP concentrations that were significantly higher $(\mathrm{P}=<0.001)$ than the conventionally produced broilers, this was attributed to restriction of prophylactic medicines coupled with access to the outside (Tuyttens et al., 2008).. 
Table 2 Studies of bacterial, viral, parasitic, immune-mediated and metabolic diseases in chickens that have measured acute phase proteins.

\begin{tabular}{|c|c|c|c|}
\hline \multicolumn{2}{|c|}{ Infectious agent } & \multirow{2}{*}{$\begin{array}{l}\mathbf{A P P} \\
\mathrm{CP}\end{array}$} & \multirow{2}{*}{$\begin{array}{l}\text { Reference } \\
\text { Nazifi et al., } 2010\end{array}$} \\
\hline \multirow[t]{17}{*}{ Viral } & Infectious bursal disease virus & & \\
\hline & & SAA & Nazifi et al., 2010 \\
\hline & & PIT54 & Nazifi et al., 2010 \\
\hline & & FB & Nazifi et al., 2010 \\
\hline & & OVT & Xie et al., 2002b \\
\hline & & MBL & Nielsen et al., 1998a; 1999 \\
\hline & Infectious bronchitis virus & SAA & Nazifi et al., 2011 \\
\hline & & OVT & Xie et al., 2002b \\
\hline & & AGP & Nakamura et al., 1996 \\
\hline & & MBL & Juul-Madsen et al., 2003; 2007 \\
\hline & Respiratory enteric orphan virus & OVT & Xie et al., 2002b \\
\hline & Fowl Poxvirus & OVT & Xie et al., 2002b \\
\hline & Infectious laryngotracheitis virus & OVT & Xie et al., 2002b \\
\hline & & AGP & Nakamura et al., 1996 \\
\hline & & MBL & Nielsen et al., 1998b; 1999 \\
\hline & Low pathogenic avian influenza & AGP & Sylte and Suarez, 2012 \\
\hline & & OVT & Sylte and Suarez, 2012 \\
\hline \multirow[t]{25}{*}{ Bacterial } & Escherichia coli (LPS) & $\mathrm{CP}$ & Butler et al., 1972 \\
\hline & & & Takahashi et al., 2009 \\
\hline & & OVT & Xie et al., 2002b \\
\hline & & & Hallquist and Klasing, 1994 \\
\hline & & AGP & Takahashi et al., 1994; 1995; 2009 \\
\hline & & & Nakamura et al., 1998 \\
\hline & & & Buyse et al., 2007 \\
\hline & & HX & Barnes et al., 2002 \\
\hline & & & Buyse et al., 2007 \\
\hline & & CRP & Patterson and Mora 1964; 1965 \\
\hline & Salmonella ser Typhimurium (LPS) & $\mathrm{CP}$ & Song et al., 2009 \\
\hline & & & Koh et al., 1996 \\
\hline & & OVT & Xie et al., 2000 \\
\hline & & $\mathrm{HX}$ & Adler et al., 2001 \\
\hline & & PIT54 & Millet et al., 2007 \\
\hline & & MBL & Millet et al., 2007 \\
\hline & Salmonella ser Gallinarum & $\mathrm{Cp}$ & Garcia et al., 2009 \\
\hline & & PIT54 & Garcia et al., 2009 \\
\hline & & OVT & Garcia et al., 2009 \\
\hline & & $\mathrm{HX}$ & Garcia et al., 2009 \\
\hline & Staphylococcus aureus & SAA & Chamanza et al., 1999a \\
\hline & & & Upragarin, 2005 \\
\hline & & CRP & Patterson and Mora, 1964 \\
\hline & Pasteurella multocida & MBL & Schou et al., 2010 \\
\hline & & CRP & Patterson and Mora, 1964 \\
\hline \multirow[t]{8}{*}{ Parasitic } & Eimeria tenella & $\mathrm{CP}$ & Georgieva et al., 2010 \\
\hline & & PIT54 & Georgieva et al., 2010 \\
\hline & & FB & Georgieva et al., 2010 \\
\hline & & OVT & Rath et al., 2009 \\
\hline & & $\mathrm{CP}$ & Richards and Augustine, 1988 \\
\hline & Eimeria maxima & OVT & Rath et al., 2009 \\
\hline & Eimeria acervulina & $\mathrm{CP}$ & Richards and Augustine, 1988 \\
\hline & Histomoniasis & CRP & Patterson and Mora, 1964 \\
\hline $\begin{array}{l}\text { Immune } \\
\text { mediated }\end{array}$ & Autoimmune vitiligo & OVT & Rath et al., 2009 \\
\hline \multirow[t]{3}{*}{ Metabolic } & Tibial dyschondroplasia & OVT & Rath et al., 2009 \\
\hline & Pulmonary hypertension & OVT & Rath et al., 2009 \\
\hline & Femoral head separation & OVT & Durairaj et al., 2009 \\
\hline
\end{tabular}




\section{OVOTRANSFERRIN}

The transferrins are a family of metal binding transport proteins with an in vivo preference for binding ferric iron (Aguilera et al., 2003). Mammals have serum transferrin, synthesised in the liver and lactoferrin a major milk protein, synthesised in the mammary gland. Chickens have neither of these proteins, instead synthesising ovotransferrin (OVT) in the liver in response to proinflammatory cytokines and in the oviduct under the influence of oestrogen (Hallquist and Klasing, 1994). Historically the word conalbumin was used to describe both the egg and serum transferrin in chickens.

Williams (1968) as well as advocating ovotransferrin (OVT) as a more informative name to describe the egg protein, demonstrated that both serum and egg OVT were the same protein differing only in their glycosylation. More recently serum transferrin has adopted the "ovo-' and the word ovotransferrin is frequently used to describe both egg and serum transferrin in chickens. OVT is a positive APP in chickens (Hallquist and Klasing, 1994; Xie et al., 2002a) with a number of studies confirming that serum OVT increases during an APR due to a variety of experimentally induced infections and inflammatory processes (Table 2). This differs from mammals where serum transferrin is a negative APP with expression being down regulated during inflammation (Ceron et al., 2005). Egg OVT responds in a negative fashion during an APR, with the oviduct magnum decreasing mRNA synthesis for egg OVT with a resultant cessation to egg laying (Hallquist and Klasing, 1994).

Serum OVT like other members of the transferrin family is an antibacterial protein, able to sequester, store and transport iron. Sequestering iron deprives bacteria of the iron essential for growth (Xie et al., 2002b). A direct action on the Gram negative bacteria $E$. coli has been identified as OVT is able to permeate the outer membrane causing bacteriostasis (Aguilera et al., 2003). OVT has immunomodulatory effects inducing respiratory burst activity and degranulation in heterophils and macrophages, and facilitates tissue remodelling and angiogenesis, aiding post inflammatory repair of tissues (Xie et al., 2002c). Xie et al. (2002b) investigated the serum OVT levels in response to a number of viruses and E. coli (Table 3). Rath et al. (2009) compared changes in the serum OVT concentration due to infectious diseases, metabolic diseases and autoimmune disease. Infectious diseases showed the biggest elevation, increasing OVT up to four fold. Autoimmune vitiligo resulted in an increase in serum OVT though the birds with tibial dyschondroplasia, pulmonary hypertension syndrome and femoral head separation disorder did not show elevations in serum OVT (Durairaj et al., 2009; Rath et al., 2009). It was postulated from these results that as well as inflammation or infection, tissue injury was needed to evoke a rise in OVT (Rath et al., 2009). It appears that increases in OVT are only evident with pathogenic challenge and the increases seen in birds with the autoimmune disorder was most likely due to the pathologically high levels of proinflammatory cytokines that are stimulatory to OVT synthesis. In investigating the response of APPs to LPAI vaccination and infection, Sylte and Suarez (2012) also measured OVT alongside AGP and found that chickens receiving a LPAI vaccine had significantly lower serum OVT at 48 and 96 hours post infection than those chickens that did not receive the vaccine.

\section{CERULOPLASMIN}

Ceruloplasmin (CP) is a vertebrate plasma protein and contains over $95 \%$ of copper found in the plasma (Martínez-Subiela et al., 2007). Avian blood is very low in copper compared to mammals and has lower serum levels of CP (Disilvestro and Harris, 1985). Ceruloplasmin is a multifunctional protein both storing and transporting copper within the body. Ceruloplasmin donates copper in a regulatory fashion with evidence of $\mathrm{CP}$ receptors on the membranes of numerous different cell types, supporting CP's role as a 
cell signalling multifunctional enzyme within many different metabolic pathways (Floris et al., 2000). Ceruloplasmin is an antioxidant protein, scavenging reactive oxygen species and preventing their formation through its involvement in iron homeostasis. Historically, preventing iron-induced oxidative stress has been considered to be the principle role of the protein in vivo (Floris et al., 2000).

Butler et al. (1972) first described CP as an APP in chickens when it was noted that a single injection of endotoxin from E. coli increased serum CP levels by two to five fold, the increase varying with the strain of $E$. coli used. The maximal increase in CP levels was 24 hours post injection with levels still detectable 48 hours after injection. Further studies confirmed CP as a positive acute phase reactant. Salmonella gallinarum delivered into the crop of chickens showed CP to increase the quickest of all the APPs measured in this study, with peak serum CP levels measured three to five days post infection (Garcia et al., 2009). Serum CP will increase significantly in response to Eimeria tenella infection (Richards and Augustine, 1988; Georgieva et al., 2010) and combined E. coli and E. tenella infection (Georgieva et al., 2010). Infection of Eimeria acervulina did not significantly increase CP concentrations (Richards and Augustine, 1988). Nazifi et al. (2010) found CP to decrease in chickens infected IBDV and the decrease was even more pronounced in the most severely infected. It would be valuable to establish whether CP shows a negative APP response in other viral infections in chickens or if this is an IBDV associated response.

\section{FIBRINOGEN}

Fibrinogen (FB) is a soluble glycoprotein present in the plasma of all vertebrates (Ceron et al., 2005). Synthesised by hepatocytes, FB functions as a key regulator of inflammation during disease. The pro-inflammatory functions of FB, fibrin and derivative peptides are associated with their ability to bind to and activate a wide range of immune cells. Importantly the pro-inflammatory functions of FB are a product of FB signalling through binding sites that do not overlap with those involved in the coagulation cascade (Davalos and Akassoglou, 2012). During an APR the vascular disruption associated with pathological events such as inflammation, infection and tissue injury cause the concentration of fibrinogen in the blood to increase (Davalos and Akassoglou, 2012). As well as providing a substrate for fibrin formation FB also provides a matrix for the migration of inflammatory related cells and for tissue repair (Murata et al., 2004).

FB is an established APP in chickens, increasing two to two and a half fold as a result of turpentine injection, with levels peaking two to three days post injection and returning to normal values by seven days (Amrani et al., 1986; Grieninger et al., 1986). Georgieva et al. (2010) found FB levels increased significantly $(\mathrm{P}=<0.001)$ in response to combined infection of $E$. coli and E. tenella and with a single infection of $E$. coli or E. tenella, with serum concentrations increasing fourfold with the $E$. coli infection. FB when studied during IBDV infection was not shown to increase significantly (Nazifi et al., 2010).

\section{FIBRONECTIN}

Fibronectin (FN) is large a molecular weight glycoprotein synthesised in hepatocytes as a soluble plasma FN and in tissues as an insoluble structural form of FN, synthesised in fibroblasts, epithelial cells and other differentiated cell types (Labat-Robert, 2012). FN is widely expressed in multiple cell types and is critically important in vertebrate development (Pankov and Yamada, 2002). In tissues FN is an extracellular matrix (ECM) glycoprotein playing an important role in the assembly and organisation of the matrix and mediating a wide variety of cellular interactions. Within the matrix FN has a wide variety of functional activities including cell adhesion, migration, growth and differentiation. FN is able to bind biologically important molecules having binding 
sites for bacteria, collagen, fibrin, FN itself and heparin (Pankov and Yamada, 2002; Labat-Robert, 2012). Plasma FN is a minor APP, increasing during an APR and able to diffuse into tissues and form part of the fibrillar matrix (Labat-Robert, 2012) where, together with tissue FN, it plays an important and active role in wound healing.

In chickens, Amrani et al. (1986) found plasma FN levels increased two and a half fold as a result of turpentine injection, rapidly peaking two days post injection and remaining elevated 52 hours after the injection. To investigate the effect of increased temperature on FN concentration, broilers were exposed to an elevated temperature $\left(42^{\circ} \mathrm{C}\right)$ for three hours; 28 hours after exposure FN concentration was significantly higher (JianHua et al., 2000). In response to ACTH and dexamethasone administration, FN in chicken plasma increased 1.6 and 2.5 fold respectively from basal levels and remained elevated for 52 hours (LiCheng et al., 2000).

\section{Haem binding proteins}

Under certain pathological conditions such as infection the red blood cell membrane can destabilise resulting in the lyses of the cell and leakage of haemoglobin into circulation (Wicher and Fries, 2006). Haemoglobin outside the cell is toxic, proinflammatory and pro-oxidative causing damage to cells and tissues and haem associated iron will support microbial growth (Ceron et al., 2005; Wicher and Fries, 2010). Plasma proteins have therefore evolved that bind free haemoglobin and haem and mediate their removal from the circulation (Wicher and Fries, 2010).

\section{PIT54}

Haptoglobin is the major haemoglobin binding protein found in mammals. The haemoglobin binding protein in chickens was considered to be haptoglobin or a haptoglobin-like protein until detailed analysis of this protein in chickens and the chicken genome found there to be no gene coding a protein similar to mammalian haptoglobin. Instead the protein referred to as PIT54 was identified, which fulfils a similar role in chickens as haptoglobin does in mammals (Iwasaki et al., 2001; Wicher and Fries, 2006). PIT54 is found only in avian species having been identified in geese, ostriches and emus. Although absent in chickens, haptoglobin is found in paleognathus birds (ostriches and emus) where haptoglobin has been conserved alongside PIT54 (Wicher and Fries, 2010).

Haptoglobin is an anti-inflammatory protein, it modulates prostaglandin synthesis and inhibits granulocyte chemotaxis and phagocytosis (Ceron et al., 2005). PIT54 evolved from an anti-inflammatory protein which evolved haemoglobin binding ability (Wicher and Fries, 2010) and it is likely that PIT54, like haptoglobin retains these antiinflammatory properties. PIT54 has been shown to have potent antioxidant properties, inhibiting superoxide production by phagocytes, thus inhibiting the overproduction of reactive oxygen species (Iwasaki et al., 2001) that cause oxidative damage. PIT54 is antibacterial as binding free haemoglobin renders it unavailable for bacterial growth. Haemoglobin iron availability and the susceptibility to infection are intimately linked with pathological iron overload predisposing to bacterial infection (Ascenzi et al., 2005).

Nazifi et al. $(2010 ; 2011)$ found that chickens had no significant increase in PIT54 during IBDV infection, yet had a significant increase as a result of IB infection. As a result of parenteral administration of $S$. typhimurium LPS, mean PIT54 serum concentrations significantly increased 1.5 fold (Millet et al., 2007). Garcia et al. (2009) found that intra-crop inoculation of S. gallinarum increased PIT54 throughout the course of a 10 day infection. Georgieva et al. (2010) compared serum PIT54 after 
experimental infection with E. coli, E. tenella and combined infection of both pathogens. The increase in PIT54 was highly significant as a result of $E$. coli infection and combined infection however serum PIT54 levels did not increase significantly as a result of $E$. tenella infection alone.

\section{HAEMOPEXIN}

Haemopexin (HX) is a haem binding protein and an established APP in chickens (Grieninger et al., 1986; Adler et al., 2001). HX binds to the non-protein pyrrole rings within the haem molecule. Its predominant function is to sequester and transport haem, though it is a multifunctional protein having involvement in iron homeostasis, antioxidant production and signalling pathways that promote cell survival and gene expression (Tolosano et al., 2010). Barnes et al. (2002), using E. coli LPS to induce an APR found a 2.6 fold increase in HX. Adler et al. (2001) used S. typhimurium LPS and complete Freund's adjuvant and found HX levels to increase three fold at 24 hours post infection, HX levels were still significantly higher than the control birds 14 days after the LPS challenge. Garcia et al. (2009) found HX to increase by approximately one and a half fold in response to intra crop $S$. gallinarum, with serum concentration decreasing from seven days post infection. Mammalian plasma HX declines between 24-72 hours post challenge. Establishing the behaviour of HX in response to different infections over a period longer than 14 days would allow HX behaviour during an APR to be fully characterised in chickens.

\section{C-reactive protein}

Originally named for its ability to bind C-polysaccharide of Pneumococcus, pneumonia, C-reactive protein (CRP) was the first described APP (Abernethy and Avery, 1941) and has been defined in humans as a highly sensitive marker of inflammation and tissue damage. CRP is a major APP in humans and dogs and is the most frequently measured APP in veterinary species (Eckersall and Bell, 2010). CRP binds directly to degenerating cells and cell remnants acts as an opsonin binding residues and polysaccharides on bacteria, fungi and parasites to activate complement and phagocytosis. CRP can also up regulate and down regulate cytokine production and chemotaxis (Gruys et al., 2005; Cray et al., 2009).

Patterson and Mora (1964) purified CRP from chicken serum and developed an assay to detect the presence or absence of CRP in chicken serum. They found CRP to be present in birds with E. coli, Pasturella multocida and Staphylococcus aureus infections, as well as histomoniasis and adjuvant injection. The authors also found CRP positive birds in a clinically normal population. These positive birds, on post mortem, had lesions consistent with chronic respiratory disease, highlighting the use of CRP as a potential biomarker for non-clinical disease. Whether CRP is a major APP in chickens as it is in humans and other veterinary species is yet to be established. Patterson and Mora (1965) found that CRP did not rise in chickens as quickly as it does in humans, whereby CRP was detectable 36-48 hours post infection in chickens, compared to $16-18$ hours in humans. It was also noted that the CRP concentration, though not quantified, appeared lower in chickens than in comparative human samples. A more recent study investigated CRP serum concentrations using a human CRP kit and found CRP concentrations to increase (Sohail et al., 2010). 


\section{Mannan binding lectin}

Mannan binding lectin (MBL) belongs to a group of proteins called collectins which have a carbohydrate recognition domain able to bind a variety of microorganisms including bacteria, viruses, fungi and parasites. Mannan binding lectin, upon recognition of infectious agents, activates a number of cellular defence mechanisms including phagocytosis, modulation of cytokines and immunoglobulin secretion. Mannan binding lectin is also able to activate the complement system through a distinct MBL pathway (Nielsen et al., 1999; Juul-Madsen et al., 2003; Schou et al., 2010).

In chickens, MBL behaves as an minor APP with ILTV, IBDV and IB, increasing serum MBL two fold with peak increases seen three to seven days post infection, with a return to normal values at six to ten days (Nielsen et al., 1998a; Nielsen et al., 1999). In relation to bacterial infections, MBL showed a significant two fold increase when chickens were inoculated with S. typhimurium LPS (Millet et al., 2007). Although classed as a minor acute phase reactant, MBL plays an active and prominent role in the immune response. When examining the baseline serum MBL concentrations in relation to intra-tracheal inoculation of P. multocida, Schou et al. (2010) found that chickens had significantly higher mean MBL concentrations prior to infection compared to four weeks post infection, and those birds that developed a systemic infection (as determined by P. multocida invasion of spleen) following inoculation, had lower mean baseline MBL than those with no splenic invasion, suggesting MBL plays a role in the chickens immune system in protecting against systemic $P$. multocida infection. Immuno-histochemical staining for MBL in healthy chickens detected MBL in the cytoplasm of a few hepatocytes and germinal centres of the caecal tonsils. In birds infected with ILTV an intense staining for MDL was detected in the cytoplasm of all hepatocytes and on the surface of and inside ILTV infected cells. IBDV infected birds had intense staining for MBL in the hepatocyte cytoplasm but no staining was observed in the follicles of the bursa of Fabricius, though MBL was present in the spleen. The presence of MBL in infected and lymphatic tissues is indicative of an important and active role within the immune system (Nielsen et al., 1998b). Studies have also revealed expression of MBL to be genetically influenced. Juul-Madsen et al. (2007) selected two lines of chickens for low and high levels of serum MBL concentration. At the sixth generation, MBL levels were found to be significantly higher in the high line and lower in the low line. Furthermore, when experimentally infected with IB virus,. there was a 2.3 fold and 1.6 fold increase in MBL in the low and high lines respectively (Juul-Madsen et al., 2007).

\section{Measuring APPs in chickens}

APPs can be measured in plasma or serum. However, in avian species, plasma is more often used because it is easier to collect than serum and yields a larger sample volume (Hrubec et al., 2002). Blood samples can be collected into anticoagulants such as EDTA or heparin and then be centrifuged to separate the cells. Heparin is reported as the preferable anticoagulant for avian species owing to its low biologic activity and lack of interference with analyte detection (Hrubec et al., 2002). Although the effect of both anticoagulants on plasma APP measurement has not been investigated in chickens, in mammalian species CP values were significantly higher with heparin than EDTA and increases in haptoglobin concentrations have been found when measured in a heparin sample (Ceron et al., 2005). The effect of anticoagulant choice on APP concentrations appears to be small in mammalian species (Ceron et al., 2005) however determining the 
effect of anticoagulants on measurable APP concentrations in chickens would allow more meaningful comparison of different studies, especially for the minor APPs, where only two or three fold changes are detected. If measuring fibrinogen or fibronectin (which coprecipitates with fibrinogen, (Labat-Robert and Robert 2012) then a plasma sample is essential as a serum sample will not contain the clotting constituents.

Samples should not be haemolysed or lipaemic as this will affect the result of APPs measured by immunoturbidimetric assays (Ceron et al., 2005) Samples can be frozen and stored at $-20^{\circ} \mathrm{C}$ and APPs remain stable at this temperature for up to two months (Ceron et al., 2005). Lower temperatures are required for longer storage. Freeze thaw cycles should be avoided, and samples should be alliquoted if necessary.

Table 3 contains references for methods or commercial kits that have been used to measure chicken APPs. All methods used should be validated for measuring chicken APPs especially when using antibodies against mammalian APPs. The availability of the AGP kit, which utilises chicken specific antibody, makes this one of the most widely measured APPs in chickens. Many labs investigating chicken APPs develop their own assays by raising antibody to the purified chicken APP.

Table 3 How to measure acute phase proteins in chickens.

\begin{tabular}{|c|c|}
\hline APP & Measurement \\
\hline Ceruloplasmin & $\begin{array}{l}\text { Indirectly measured using p-phenylenediamine (PPD) oxidase } \\
\text { activity (Sunderman and Nomoto 1970; Martínez-Subiela et al., 2007) }\end{array}$ \\
\hline Fibrinogen & Heat precipitation method (Thrall et al., 2004) \\
\hline Fibronectin & ELISA (Lynagh et al., 2000) \\
\hline OVT & ELISA (Xie et al., 2002b; Rath et al., 2009) \\
\hline PIT54 & $\begin{array}{l}\text { Commercially available kits for measuring haptoglobin are based on } \\
\text { the haemoglobin binding activity (Eckersall et al., 1999) are effective with } \\
\text { chicken PIT54 }\end{array}$ \\
\hline Haemopexin & $\begin{array}{l}\text { Rocket gel electrophoresis using a rabbit anti-chicken hemopexin } \\
\text { (Adler et al., 2001) }\end{array}$ \\
\hline SAA & $\begin{array}{l}\text { Mouse SAA antibody solid phase sandwich ELISA available from Tridelta (Ireland) } \\
\text { (Nazifi et al., 2010) }\end{array}$ \\
\hline MBL & Sandwich ELISA (Laursen et al., 1998) \\
\hline$\alpha-1$ - glycoprotein & $\begin{array}{l}\text { Specific chicken single immunodiffusion test kit available using anti-chicken } \\
\text { AGP antibodies of rabbit origin (ECOS Institute, Miyagi, Japan) }\end{array}$ \\
\hline
\end{tabular}

As well as ELISA methods, gel based methods can also be used to quantify APPs. Garcia et al. (2009) used SDS PAGE gels with samples compared to purified APPs and the concentration of the APP calculated using a scanning densitometer. Combined antibody and gel methods also work very well, such as the AGP kit (Table 3) and that used by (Adler et al., 2001) to measure HX. Commercially available kits for measuring haptoglobin in mammals also respond to PIT54 in chickens. APPs have been used in a number of studies of infectious diseases. Table 2 summarises the APPs that have been measured in chickens with bacterial, viral, parasitic, immunemediated and metabolic diseases.

\section{Conclusions}

Chamanza et al. (1999b) produced a substantial review of APPs in the domestic fowl in 1999. At the time measuring APPs in poultry species was in its infancy, no kits were commercially available and the number of diseases in which APPs had been studied was 
limited. Since then research into APPs in poultry species, especially the chicken, has developed widely to include many infectious diseases as well as welfare and nutritional studies. Since the last review many APPs have been identified in the chicken and more detailed information about chicken APPs, their structure and how they respond during an APR is available.

Many of the APPs still require further research either to fully determine their behaviour in the chicken or to pave way for the development of chicken specific assays which would expand the measurement of APPs in chickens beyond the research environments. A small number of proteomic investigations in chickens, have harnessed two-dimensional protein methodologies and found them to yield a high level of information on how the plasma proteome changes in response to disease. This expanding area may give rise to the identification of other APPs and biomarkers of disease. Other production species have utilised APP measurement as biomarkers for health and disease and as a selection tool for breeding programmes. Ongoing work is continuing to elaborate on the role APPs play in the immune system of the chicken and this will be advanced greatly by the increased availability of assays validated for chickens and concurrent proteomic investigations.

\section{References}

ABERNETHY, T. and AVERY, O. (1941) The occurrence during acute infections of a protein not normally present in the blood. The Journal of Experimental Medicine 73: 173-182.

ADLER, K.L., PENG, P.H., PENG, R.K. and KLASING, K.C. (2001) The Kinetics of Hemopexin and $\alpha 1-$ Acid Glycoprotein Levels Induced by Injection of Inflammatory Agents in Chickens Inflammatory Agents in Chickens. Avian Diseases 45: 289-296.

AGUILERA, O., QUIROS, L.M. and FIERRO, J.F. (2003) Transferrins selectively cause ion efflux through bacterial and artificial membranes. FEBS Letters 548: 5-10.

AlASONYAlilar, A., SEVIMLI, A., MiSIRLIOGLU, D. and UGUZ, C. (2006) Chronic amyloid arthropathy and increased serum amyloid levels in brown layers. The Bulletin of the Veterinary Institute in Pulawy 50: 557-560.

AMRANI, D.L., MAUZY-MELITZ, D. and MOSESSON, M.W. (1986) Effect of hepatocyte-stimulating factor and glucocorticoids on plasma fibronectin levels. The Biochemical Journal 238: 365-371.

ASCENZI, P., BOCEDI, A., VISCA, P., ALTRUdA, F., TOLOSANO, E., BERINGHELLI, T. and FASANO, M. (2005) Hemoglobin and heme scavenging. IUBMB life 57: 749-759.

BARNES, D.M., SONG, Z., KLASING, K.C. and BOTTJE, W. (2002) Protein metabolism during an acute phase response in chickens. Amino acids 22: 15-26.

BUTLER, E.J., CURTIS, M.J., HARRY, E.G. and DEB, J.R. (1972) Effects of Escherichia coli endotoxins on plasma para-phenylenediamine oxidase (caeruloplasmin) activity in the domestic fowl. Journal of Comparative Pathology 82: 299-306.

BUYSE, J., SWENNEN, Q., NIEWOLD, T.A., KLASING, K.C., JANSSENS, G.P.J., BAUMGARTNER, M. and GODDEERIS, B. (2007) Dietary L-carnitine supplementation enhances the lipopolysaccharideinduced acute phase protein response in broiler chickens. Veterinary Immunology and Immunopathology 118 : 154-159.

CECILIANI, F. and POCACQUA, V. (2007) The acute phase protein 1-acid glycoprotein: a model for altered glycosylation during diseases. Current Protein and Peptide Science 8: 91-108.

CERON, J.J., ECKERSALL, P.D. and MARTÝNEZ-SUBIELA, S. (2005) Acute phase proteins in dogs and cats: current knowledge and future perspectives. Veterinary Clinical Pathology 34: 85-99.

CHAMANZA, R., TOUSSAINT, M.J.M., VAN EDEREN, A.M., VAN VEEN, L., HULSKAMP-KOCH, C. and FABRI, T.H.F. (1999a) Serum amyloid a and transferrin in chicken. A preliminary investigation of using acute-phase variables to assess diseases in chickens. Veterinary Quarterly 21: 37-41.

CHAMANZA, R., VAN VEEN, L., TIVAPASI, M.T. and TOUSSAINT, M.J.M. (1999b) Acute phase proteins in the domestic fowl. World's Poultry Science Journal 55: 61-71.

CRAY, C., ZAIAS, J. and ALTMAN, N.H. (2009) Acute phase response in animals: a review. Comparative Medicine 59: 517-526.

DAVALOS, D. and AKASSOGLOU, K. (2012) Fibrinogen as a key regulator of inflammation in disease. Seminars in Immunopathology 34: 43-62. 
DISILVESTRO, R.A. and HARRIS, E.D. (1985) Purification and partial characterization of ceruloplasmin from chicken serum. Archives of Biochemistry and Biophysics 241: 438-446.

DURAIRAJ, V., OKIMOTO, R., RASAPUTRA, K., CLARK, F.D. and RATH, N.C. (2009) Histopathology and serum clinical chemistry evaluation of broilers with femoral head separation disorder. Avian Diseases 53: 21-25.

ECKERSALL, P.D., DUTHIE, S., SAFI, S., MOFFATT, D., HORADAGODA, N.U., DOYLE, S., PARTON, R., BENNETT, D. and FITZPATRICK, J.L. (1999) An Automated Biochemical Assay for Haptoglobin: Prevention of Interference from Albumin. Comparative Haemotology International 9: 117-124.

ECKERSALL, P.D. and BELL, R. (2010) Acute phase proteins: Biomarkers of infection and inflammation in veterinary medicine. The Veterinary journal 185: 23-27.

ERIKSEN, N., MEEK, R.L. and BENDITT, E.P. (1993) The SAA lipoprotein family, in: MACKIEWICZ, A., KUSHNER, I. \& BAUMANN, H. (Eds) Acute Phase Proteins: Molecular biology, Biochemistry and Clinical Applications, pp. 93-106 (CRC Press, Boca Raton, Florida).

FLORIS, G., MEDDA, R., PADIGLIA, A. and MUSCI, G. (2000) The physiopathological significance of ceruloplasmin. Biochemical Pharmacology 60: 1735-1741.

GARCIA, K.O., BERCHIERI-JUNIOR, A., SANTANA, A.M., FREITAS-NETO, O.C. and FAGLIARI, J.J. (2009) Experimental infection of commercial layers using a Salmonella enterica serovar Gallinarum strain: Leukogram and serum acute-phase protein concentrations. Brazillian Journal of Poultry Science 11: 263-270.

GEORGIEVA, T.M., KOINARSKI, V.N., URUMOVA, V.S., MARUTSOV, P.D., CHRISTOV, T.T., NIKOLOV, J., CHAPRAZOV, T., WALSHE, K., KAROV, R.S., GEORGIEV, I.P. and KOINARSKI, Z.V. (2010) Effects of Escherichia coli infection and Eimeria tenella invasion on blood concentrations of some positive acute phase proteins (haptoglobin (PIT 54), fibrinogen and ceruloplasmin). Revue de Medecine Veterinaire 161: 84-89.

GRIENINGER, G., LIANG, T.J., BEUVING, G., GOLDFARB, V., METCALFE, S.A. and MULLEREBERHARD, U. (1986) Hemopexin is a developmentally regulated, acute-phase plasma protein in the chicken. The Journal of Biological Chemistry 261: 15719-15724.

GRUYS, E., TOUSSAINT, M.J.M., NIEWOLD, T.A. and KOOPMANS, S.J. (2005) Acute phase reaction and acute phase proteins. Journal of Zhejiang University. Science B 6: 1045-1056.

HALLQUIST, N.A. and KLASING, K.C. (1994) Serotransferrin, ovotransferrin and metallothionein levels during an immune response in chickens. Comparative Biochemistry and Physiology Part B: Comparative Biochemistry 108: $375-384$.

HRUBEC, T., WHICHARD, J.M., LARSEN, C.T. and PIERSON, M.S. (2002) Plasma versus serum: specific differences in biochemical analyte values. Journal of Avian Medicine and Surgery 16: 101-105.

INOUE, M., SATOH, W. and MURAKAMI, H. (1997) Plasma alpha 1-acid glycoprotein in chickens infected with infectious bursal disease virus. Avian Diseases 41: 164-170.

IWASAKI, K., MORIMATSU, M., INANAMI, O., UCHIDA, E., SYUTO, B., KUWABARA, M. and NIIYAMA, M. (2001) Isolation, characterization, and cDNA cloning of chicken turpentine-induced protein, a new member of the scavenger receptor cysteine-rich (SRCR) family of proteins. The Journal of Biological Chemistry 276: 9400-9405.

JIANHUA, L., LICHENG, L., JIUSHAN, J. and HONGKUI, L. (2000) Effects of high temperature on plasma fibronectin levels and serum biochemical parameters in broilers. Chinese Journal of Veterinary Science 20: 591-593.

JUUL-MADSEN, H.R., MUNCH, M., HANDBERG, K.J., SØRENSEN, P., JOHNSON, A.A., NORUP, L. R. and JØRGENSEN, P.H. (2003) Serum levels of mannan-binding lectin in chickens prior to and during experimental infection with avian infectious bronchitis virus. Poultry Science 82: 235-241.

JUUL-MADSEN, H.R., NORUP, L.R., HANDBERG, K.J. and JØRGENSEN, P.H. (2007) Mannanbinding lectin (MBL) serum concentration in relation to propagation of infectious bronchitis virus (IBV) in chickens. Viral Immunology 20: 562-570.

KOH, T.S., PENG, R.K. and KLASING, K.C. (1996) Dietary copper level affects copper metabolism during lipopolysaccharide-induced immunological stress in chicks. Poultry Science 75: 867-872.

LABAT-ROBERT, J. (2012) Cell-Matrix interactions, the role of fibronectin and integrins. A survey Pathologie-Biologie 60: 15-19.

LABAT-ROBERT, J. and ROBERT, L. (2012) Fifty years of structural glycoproteins. Pathologie-Biologie 60: $66-75$.

LANDMAN, W., GRUYS, E. and DWARS, R. (1994) A syndrome associated with growth depression and amyloid arthropathy in layers: a preliminary report. Avian Pathology 23: 461- 470.

LANDMAN, W.J.M. (1998) Amyloid Arthropathy. Ph. D. thesis, Utrecht University.

LAURSEN, S.B., HEDEMAND, J.E., NIELSEN, O.L., THIEL, S., KOCH, C. and JENSENIUS, J.C. (1998) Serum levels, ontogeny and heritability of chicken mannan-binding lectin (MBL). Immunology 94: $587-593$ 
LAURSEN, S.B. and NIELSEN, O.L. (2000) Mannan-binding lectin (MBL) in chickens: molecular and functional aspects. Developmental and Comparative Immunology 24: 85-101.

LICHENG, L., JIANHUA, L., JIUSHAN, J., JIXUN, Z. and CHENG, H. (2000) Effect of ACTH and dexamethasone on plasma fibronectin levels and serum biochemical parameters in broilers. Journal of China Agricultural University 5: 106 -110.

LYNAGH, G.R., COLLINS, R.A. and KAISER, P. (2000) Development and use of monoclonal antibodies to chicken fibronectin to show that the chicken hepatocellular carcinoma cell line, LMH, constitutively expresses fibronectin. Research in Veterinary Science 68: 147-152.

MARTÍNEZ-SUBIELA, S., TECLES, F. and CERON, J.J. (2007) Comparison of two automated spectrophotometric methods for ceruloplasmin measurement in pigs. Research in Veterinary Science 83: 12-19.

MILLET, S., BENNETT, J., LEE, K.A., HAU, M. and KLASING, K.C. (2007) Quantifying and comparing constitutive immunity across avian species. Developmental and Comparative Immunology 31: 188-201.

MURATA, H., SHIMADA, N. and YOSHIOKA, M. (2004) Current research on acute phase proteins in veterinary diagnosis: an overview. The Veterinary Journal 168: 28-40.

NAKAMURA, K., MITARAI, Y. and YOSHIOKA, M. (1998) Serum levels of interleukin-6, alpha1-acid glycoprotein, and corticosterone in two-week-old chickens inoculated with Escherichia coli lipopolysaccharide. Poultry Science 77: 908-911.

NAKAMURA, K., IMAI, K. and TANIMURA, N. (1996) Comparison of the effects of infectious bronchitis and infectious laryngotracheitis on the chicken respiratory tract. Journal of Comparative Pathology 114: 1121.

NAZIFI, S., TABANDE, M.R., HOSSEINIAN, S.A., ANSARI-LARI, M. and SAFARI, H. (2011) Evaluation of sialic acid and acute-phase proteins (haptoglobin and serum amyloids A) in healthy and avian infection bronchitis virus-infected chicks. Comparative Clinical Pathology 20: 69-73.

NAZIFI, S., DADRAS, H., HOSEINIAN, S.A., ANSARI-LARI, M. and MASOUDIAN, M. (2010) Measuring acute phase proteins (haptoglobin, ceruloplasmin, serum amyloid A, and fibrinogen) in healthy and infectious bursal disease virus-infected chicks. Comparative Clinical Pathology 19: 283-286.

NIELSEN, O.L., SØRENSEN, P., HEDEMAND, J.E., LAURSEN, S.B. and JØRGENSEN, P.H. (1998a) Inflammatory response of different chicken lines and B haplotypes to infection with infectious bursal disease virus. Avian Pathology 27: 181-189.

NIELSEN, O.L., JØRGENSEN, P.H., HEDEMAND, J., JENSENIUS, J.C., KOCH, C. and LAURSEN, S. B. (1998b) Immunohistochemical investigation of the tissue distribution of mannan-binding lectin in noninfected and virus-infected chickens Immunology 94: 122-128.

NIELSEN, O.L., JENSENIUS, J.C., JØRGENSEN, P.H. and LAURSEN, S.B. (1999) Serum levels of chicken mannan-binding lectin (MBL) during virus infections; indication that chicken MBL is an acute phase reactant. Veterinary Immunology and Immunopathology 70: 309-316.

OVELGÖNNE, J.H., LANDMAN, W.J., GRUYS, E., GIELKENS, A.L. and PEETERS, B.P. (2001) Identical amyloid precursor proteins in two breeds of chickens which differ in susceptibility to develop amyloid arthropathy. Amyloid 8: 41-51.

PANKOV, R. and YAMADA, K.M. (2002) Fibronectin at a glance. Journal of Cell Science 115: 3861-3863.

PATTERSON, L.T. and MORA, E.C. (1964) Occurance of a substance analogous to C-reactive protein in the blood of the domestic fowl. Texas Reports on biology and medicine 22: 716-721.

PATTERSON, L.T. and MORA, E.C. (1965) The C-reactive protein response and disease resistance in domestic fowl. Texas Reports on biology and medicine 23: 600-606.

PETERSEN, H.H., NIELSEN, J.P. and HEEDAARD, P.M.H. (2004) Application of acute phase protein measurements in veterinary clinical chemistry. Veterinary Research 35: 163-187.

RATH, N.C., ANTHONY, N.B., KANNAN, L., HUFF, W.E., HUFF, G.R., CHAPMAN, H.D., ERF, G.F. and WAKENELL, P. (2009) Serum ovotransferrin as a biomarker of inflammatory diseases in chickens. Poultry Science 88: 2069-2074.

RICHARDS, M.P. and AUGUSTINE, P.C. (1988) Serum and liver zinc, copper, and iron in chicks infected with Eimeria acervulina or Eimeria tenella. Biological Trace Element Research 17: 207-219.

RÖCKEN, C. and SHAKESPEARE, A. (2002) Pathology, diagnosis and pathogenesis of AA amyloidosis. Virchows Archiv 440: 111-122.

SAlAMANO, G., MEllia, E., TARANTOLA, M., GENNERO, M.S., DOGLIONE, L. and SCHIAVONE, A. (2010) Acute phase proteins and heterophil:lymphocyte ratio in laying hens in different housing systems. The Veterinary Record 167: 749-751.

SCHOU, T.W., PERMIN, A., CHRISTENSEN, J.P., CU, H.P. and JUUL-MADSEN, H.R. (2010) Mannanbinding lectin (MBL) in two chicken breeds and the correlation with experimental Pasteurella multocida infection. Comparative Immunology, Microbiology and Infectious Diseases 33: 183-195.

SEVIMli, A., MISIRLIOĞLU, D., POLAT, U., YALÇIN, M., AKKOÇ, A. and UĞUZ, C. (2005) The effects of vitamin A, pentoxyfylline and methylprednisolone on experimentally induced amyloid arthropathy in brown layer chicks. Avian Pathology 34: 143-149. 
SHAINKIN-KESTENBAUM, R., BERLYNE, G., ZIMLICHMAN, S., SORIN, H.R. NYSKA, M. and DANON, A. (1991) Acute phase protein, serum amyloid A, inhibits IL-1- and TNF-induced fever and hypothalamic PGE2 in mice. Scandinavian Journal of Immunology 34: 179-183.

SOHAIL, M.U., IJAZ, A., YOUSAF, M.S., ASHRAF, K., ZANEB, H., ALEEM, M. and REHMAN, H. (2010) Alleviation of cyclic heat stress in broilers by dietary supplementation of mannan-oligosaccharide and Lactobacillus-based probiotic: dynamics of cortisol, thyroid hormones, cholesterol, C-reactive protein, and humoral immunity. Poultry Science 89: 1934-1938.

SONG, Z., ZHU, L., ZHAO, T., JIAO, H. and LIN, H. (2009) Effect of copper on plasma ceruloplasmin and antioxidant ability in broiler chickens challenged by lipopolysaccharide. Asian-Australasian Journal of Animal Sciences 22: 1400-1406.

SUNDERMAN, F. and NOMOTO, S. (1970) Measurement of human serum ceruloplasminby its pphenylenediamine oxidase activity. Clinical Chemistry 16: 903-910.

SYLTE, M.J. and SUAREZ, D.L. (2012) Vaccination and acute phase mediator production in chickens challenged with low pathogenic avian influenza virus; novel markers for vaccine efficacy? Vaccine 30: 3097-3105.

TAKAHASHI, K., AKIBA, Y., IWATA, T. and KASAI, M. (2002) Dietary conjugated linoleic acids alleviate early inflammatory response caused by lipopolysaccharide injection in male broiler chicks. Animal Science Journal 73: 47-50.

TAKAHASHI, K., KAJI, N., AKIBA, Y. and TAMURA, K. (1994) Plasma alpha 1-acid glycoprotein concentration in broilers: influence of age, sex and injection of Escherichia coli lipopolysaccharide. British Poultry Science 35: 427-432.

TAKAHASHI, K., MIYAKE, N. and OHTA, T. (1998) Changes in plasma alpha 1-acid glycoprotein concentration and selected immune response in broiler chickens injected with Escherichia coli lipopolysaccharide. British Poultry Science 39: 152-155.

TAKAHASHI, K., TAKAGI, K. and AKIBA, Y. (2009) Effects of dietary glycine supplementation and fish meal on inflammatory responses in broiler chicks. British Poultry Science 50: 479-486.

TAKAHASHI, K., YODOGAWA, S., AKIBA, Y. and TAMURA, K. (1995) Effect of dietary protein concentration on responses to Escherichia coli endotoxin in broiler chickens. British Journal of Nutrition 74: $173-182$.

THRALL, M.A., BAKER, D.C., CAMPBELL, T.W., DENICOLA, D.B., FETTMAN, M.J. and LASSEN, E.D. (2004) Veterinary Hematology and Clinical Chemistry (John Wiley \& Sons).

TOlOSANO, E., FAGOONEe, S., MOREllo, N., VINCHI, F. and FIORITO, V. (2010) Heme scavenging and the other facets of hemopexin. Antioxidants \& Redox Signaling 12: 305-320.

TUYTTENS, F., HEYNDRICKX, M., DE BOECK, M., MOREELS, A., VAN NUFFEL, A., VAN POUCKE, E., VAN COILlIE, E., VAN DONGEN, S. and LENS, L. (2008) Broiler chicken health, welfare and fluctuating asymmetry in organic versus conventional production systems. Livestock Science 113: $123-132$.

UHLAR, C.M. and WHITEHEAD, A.S. (1999) Serum amyloid A, the major vertebrate acute-phase reactant. European Journal of Biochemistry 265: 501-523.

UPRAGARIN, N. (2005) In vitro studies on the pathogenesis of AA amyloid arthropathy in chicken. Ph. D thesis, Utrecht University.

UPRAGARIN, N., VAN ASTEN, A.J.A.M., TOOTEN, P.C.J., LANDMAN, W.J.M. and GRUYS, E. (2005) Serum amyloid A production by chicken fibroblast-like synoviocytes. Veterinary Immunology and Immunopathology 106: 39-51.

WICHER, K.B. and FRIES, E. (2010) Evolutionary aspects of hemoglobin scavengers. Antioxidants \& Redox Signaling 12: 249-259.

WICHER, K.B. and FRIES, E. (2006) Haptoglobin, a hemoglobin-binding plasma protein, is present in bony fish and mammals but not in frog and chicken. Proceedings of the National Academy of Sciences of the United States of America 103: 4168-4173.

WIGLEY, P. and KAISER, P. (2003) Avian cytokines in health and disease. Revista Brasileira de Ciência Avícola 5: 1-14.

WILLIAMS, J. (1968) A comparison of glycopeptides from the ovotransferrin and serum transferrin of the hen. The Biochemical Journal 108: 57-67.

XIE, H., RATH, N.C., HUFF, G.R., HUFF, W.E. and BALOG, J.M. (2000) Effects of Salmonella typhimurium lipopolysaccharide on broiler chickens. Poultry Science 79: 33-40.

XIE, H., HUFF, G.R., HUFF, W.E., BALOG, J.M., HOLT, P. and RATH, N.C. (2002a) Identification of ovotransferrin as an acute phase protein in chickens. Poultry Science 81: 112-20.

XIE, H., NEWBERRY, L., CLARK, F.D., HUFF, W.E., HUFF, G.R., BALOG, J.M. and RATH, N.C. (2002b) Changes in Serum Ovotransferrin Levels in Chickens with Experimentally Induced Inflammation and Diseases Changes in Serum Ovotransferrin Levels in Chickens with Experimentally Induced Inflammation and Diseases. Avian Diseases 46: 122-131. 
Acute phase protein chicken: E.L. O'Reilly and P.D. Eckersall

XIE, H., HUFF, G.R., HUFF, W.E., BALOG, J.M. and RATH, N.C. (2002c) Effects of ovotransferrin on chicken macrophages and heterophil-granulocytes. Developmental \& Comparative Immunology 26: 805-815. 
